\title{
Multiplication, Translocation and Inactivation Patterns of Soybean Mosaic Virus Strains B and D in Soybean Plants*
}

\author{
Hisashi IWAI $^{* *, \dagger}$ and Satoshi WaKImoto**
}

\begin{abstract}
To clarify the cause of difference between soybean mosaic virus strains B (SMV-B) and D (SMV-D) in the ability of transmission through seeds, the mode of translocation, multiplication and inactivation of both SMV strains in a soybean was investigated. After soybean cultivar Hyuga was inoculated with each strain, virus concentration in the leaves and seeds was periodically assayed by bioassay and ELISA. When 3rd trifoliolate leaves were inoculated with two virus strains at V4 (4th node) stage, the concentration of SMV-D in the leaves upper than the inoculated leaves increased more vigorously and reached higher level than SMV-B on the 10th day after inoculation. After that, the concentration of both strains decreased with plant aging; that of SMV-D decreased more rapidly than SMV-B. On the 50th day after inoculation, both strains were faintly detected from the leaves lower than the inoculated leaves, and in these leaves also, decrease of SMV-D was faster than that of SMV-B. When inoculation was done to various leaves not extremely aged at different stages not later than R1 (beginning bloom stage), both SMV strains were readily translocated to the seeds set at the upper and lower nodes than the inoculated leaves. In conclusion, there was no significant difference of translocation patterns between two strains, but in every infected organ (leaf or seed) SMV-D disappeared more briefly than SMV-B.
\end{abstract}

(Received March 6, 1989)

Key words: soybean mosaic virus, multiplication, translocation, inactivation, bioassay, ELISA.

\section{INTRODUCTION}

Soybean mosaic virus (SMV) is classified into some strains based on symptoms and pathogenicity to soybean varieties ${ }^{3,8,10}$. In Japan SMV was classified into five strains, A to $\mathrm{E}^{10}$. Although these five strains could be distinguished neither serologically nor biochemically ${ }^{11)}$, they were divided into two groups, i.e., ordinary strains (A, B, C) and severe strains (D, E), by their pathogenicity ${ }^{10}$. The former group is comparatively limited in host range and causes typical mosaic and/or leaf curl. The latter group has wide host range, causing slight waving of leaf edge on the varieties susceptible to the former group, and necrosis on the varieties having genes for resistance to the former group. The more important difference between two groups is in transmissibility, viz. the former is readily transmissible by seed and aphid but the latter is very rarely ${ }^{10)}$.

* A preliminary report of this work was presented in the Annual Meeting of the Phytopathological Society of Japan, Nagoya (1986).

This experiment was supported by a Grant-in-Aid from Ministry of Education, Science and Culture of Japan (No. 61760052).

** Faculty of Agriculture, Kyushu University, Fukuoka 812, Japan 九州大学農学部

$\dagger$ Present Address: Faculty of Agriculture, Kagoshima University, Kagoshima 890, Japan 現在: 鹿児島大学農学部 
In previous investigations the authors clarified that SMV-B was detected from all tissues of immature seed, viz., seed coat, embryo and cotyledon, while SMV-D was not detected from cotyledon ${ }^{7}$. As seeds matured the detection values declined in both SMV strains, however, in mature seed, the detection value of SMV-B in the embryo was much higher than that of SMVD. From these results we concluded that the difference between the two SMV strains in seed transmission frequency is due to the differences in inactivation degree in tissues during seed maturation.

To clarify the mechanisms of the differences between SMV-B and SMV-D in transmissibility by soybean seeds in more detail, multiplication of SMV in soybean leaves, inactivation in the leaves with aging, and translocation from leaves toward seeds were examined by both methods of bioassay and ELISA after inoculation.

\section{MATERIALS AND METHODS}

$S M V$. The SMV isolate N-657) belonging to SMV-B (ordinary strain) and the type strain of SMV-D ${ }^{7)}$ (severe strain) were used. These two strains were maintained in the susceptible soybean (Glycine max (L.) Merr.) cv. Hyuga grown in a temperature-controlled greenhouse at around $25 \mathrm{C}$.

Soybean plants. The plants of soybean cv. Hyuga were grown on sterilized soil in $30 \mathrm{~cm}$ diameter clay pots (1 plant/pot) in the temperature controlled greenhouse at around $25 \mathrm{C}$ until each inoculation stage. Stage descriptions of soybean development was followed to Fehr et al. ${ }^{5)}$ as shown in Table 1.

Inoculation and sampling. To investigate translocation patterns of two virus strains in soybean leaves, the 3rd trifoliolate leaves were inoculated at V4 with virus preparation as described in the previous paper ${ }^{7}$. Three plants were used for each inoculation. On the 4th, 10th, 20th, 35th, 50th and 85th days after inoculation, which correspond to the stages of V5, V7, R1, R4, R6 and R7, respectively, disks (1 cm diameter) were sampled from the leaves of each node. To reduce sampling error, the samples were obtained from each trifoliolate leaf divided into 6 blocks of half-leaves every time, as shown in Fig. 1. The experiments were repeated two times, first from autumn to winter and second from spring to early summer. Inoculation was done at 23 (first exp.) and 24 (second exp.) days after seeding.

Table 1. Description of stages of soybean plant ${ }^{a}$ )

\begin{tabular}{|c|c|c|}
\hline Stage & $\begin{array}{l}\text { Abbreviated } \\
\text { stage title }\end{array}$ & Parts of a soybean plant at the second-node (V2) stage \\
\hline VE & Emergence & \\
\hline $\mathrm{VC}$ & Cotyledon & \\
\hline V1 & First-node & $\begin{array}{l}\text { Trifoliolate } \\
\text { leaf }\end{array}$ \\
\hline $\mathrm{V} 2$ & Second-node & \\
\hline V3 & Third-node & \\
\hline & & $\begin{array}{l}\text { Uppermost } \\
\text { node count }\end{array}$ \\
\hline$\dot{\mathrm{V}}(n)$ & $n$ th-node & Node \\
\hline $\mathrm{R} 1$ & Beginning bloom & \\
\hline $\mathrm{R} 2$ & Full bloom & \\
\hline R3 & Beginning pod & \\
\hline $\mathrm{R} 4$ & Full pod & In ifoli \\
\hline R5 & Beginning seed & leaf \\
\hline R6 & Full seed & \\
\hline $\mathrm{R} 7$ & Beginning maturity & \\
\hline $\mathrm{R} 8$ & Full maturity & \\
\hline
\end{tabular}

a) Derived from Fehr et al. (1971) ${ }^{5)}$. 


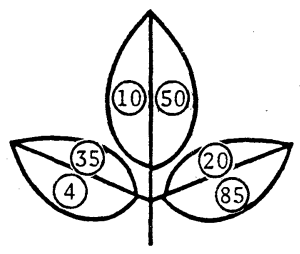

Plant I

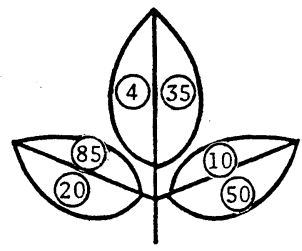

Plant II

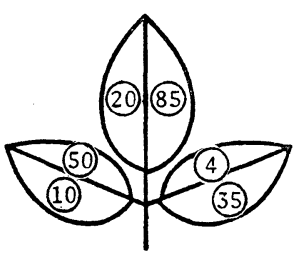

Plant III

Fig. 1. Scheme of sampling leaf disks from SMV inoculated soybean plants, cv. Hyuga. Leaf disks $(1 \mathrm{~cm}$ diameter) were periodically obtained from different three half leaves of each node of three plants. The figures in circles indicate the sampling time in number of days after inoculation.

To examine the virus translocation to seeds, SMV-B and SMV-D were inoculated to the various parts of trifoliolate leaves at various stages, viz., 1st trifoliolate leaves at V2, 1st and 3rd trifoliolate leaves at V4, 1st, 3rd and 5th trifoliolate leaves at V6, and 7th (top) trifoliolate leaves at R1, as described previously ${ }^{7}$. Each inoculation day corresponded to the 15th, 24th, $33 \mathrm{rd}$ and $42 \mathrm{nd}$ days after seeding. Two plants were inoculated with each virus strain. Virus concentration in seeds was detected at R6 by ELISA ${ }^{4}$.

Virus detection from leaf disks and seeds. Leaf disks from three plants were homogenized altogether in PBS-Tween $(1 \mathrm{ml} / 3$ disks). To detect virus in seeds, 2 to 9 seeds from each node were harvested and homogenized separately in ten-fold PBS-Tween. The homogenates thus obtained were subjected to ELISA and/or bioassay on primary leaves of French bean (Phaseolus vulgaris) cv. Top Crop?).

ELISA and bioassay procedure. Double sandwich ELISA ${ }^{4)}$ was applied for SMV detection as follows ${ }^{7}$. Immuron 1 F-form polystyrene plates (Dynatech Laboratories, Inc.) coated with the $\gamma$-globulin fraction of anti-SMV-B (N-65) serum in coating buffer were incubated for $4 \mathrm{hr}$ at $37 \mathrm{C}$. After rinsing in PBS-Tween, sample homogenates were added to each well. The plates with samples were incubated for $15 \mathrm{hr}$ at $4 \mathrm{C}$ and then washed in PBS-Tween. Alkaline phosphatase (Boehringer Mannheim)-conjugated $\gamma$-globulin diluted in PBS-Tween was added. The coating $\gamma$-globulin and enzyme-conjugated $\gamma$-globulin were used at a concentration of $5 \mu \mathrm{g} / \mathrm{ml}$ and $1 / 400$ dilution, respectively. Following incubation for $3 \mathrm{hr}$ at $37 \mathrm{C}$, the plates were washed in PBS-Tween, and substrate ( $p$-nitrophenyl phosphate) (Sigma) solution were added to each well and incubated for $1.5 \mathrm{hr}$ at $27 \mathrm{C}$. After reaction the absorbance at $405 \mathrm{~nm}$ was measured by the immuno reader NJ-2000 (Japan Intermed Co.).

For bioassay ${ }^{7)}$, the primary leaves of French bean cv. Top Crop were used. Each homogenate was inoculated on six half leaves by finger because the volume of homogenates was very small. The remaining half leaves were inoculated with purified fresh virus in $0.05 \mathrm{M}$ sodium phosphate buffer ( $\mathrm{pH} 7.0$ ) at a concentration of $20 \mu \mathrm{g} / \mathrm{ml}$ as the positive control. Just after inoculation, the inoculated leaves were rinsed with tap water, and inoculated plants were incubated in the dark room (temperature: $32 \mathrm{C}$, humidity: above $98 \%$ ) for $48 \mathrm{hr}$ until lesion development. And the means of relative infectivities were shown on result. Relative infectivity was calculated as follow: $(a / b) \times 100$, wherein $a$ was obtained by the number of lesions incited on the one side half leaf by each homogenate and $b$ was obtained by that incited on the opposite side half leaf by purified virus.

\section{RESULTS}

Translocation, multiplication, and inactivation patterns of SMV in soybean leaves

On the 4th day after inoculation (V5), SMV-B and -D were detected only from the inoculated leaves, however, in the second experiment SMV-D was also detected from the 4th trifoliolate leaves. On the 10th day after inoculation (V7), both strains SMV-B and SMV-D were 
Table 2. Detection of SMV in the leaves of

\begin{tabular}{|c|c|c|c|c|c|c|c|c|c|c|}
\hline \multirow{2}{*}{$\begin{array}{l}\text { Staged) } \\
\text { Days after } \\
\text { inoculation }\end{array}$} & \multirow{2}{*}{ Strain } & \multicolumn{9}{|c|}{ Bioassay b) } \\
\hline & & $\mathrm{U}^{\mathrm{e})}$ & 1 & 2 & $3 \mathrm{f}$ & 4 & 5 & 6 & 7 & 8 \\
\hline \multirow{2}{*}{ V5 / 4} & $\mathrm{~B}$ & 0 & 0 & 0 & 7 & 0 & $-\mathrm{g})$ & - & - & - \\
\hline & $\mathrm{D}$ & 0 & 0 & 0 & 11 & 0 & - & - & - & - \\
\hline \multirow{2}{*}{$\mathrm{V7} / 10$} & $\mathrm{~B}$ & 0 & 0 & 0 & 50 & 84 & 179 & 129 & - & - \\
\hline & $\mathrm{D}$ & 0 & 0 & 0 & 91 & 132 & 391 & 455 & - & - \\
\hline \multirow{2}{*}{$\mathrm{R} 1 / 20$} & B & 0 & 0 & 0 & 55 & 98 & 147 & 133 & 200 & 99 \\
\hline & $\mathrm{D}$ & 0 & 0 & 0 & 109 & 122 & 193 & 226 & 177 & 163 \\
\hline \multirow{2}{*}{$\mathrm{R} 4 / 35$} & $\mathrm{~B}$ & 0 & 0 & 0 & 34 & 93 & 96 & 83 & 97 & 86 \\
\hline & $\mathrm{D}$ & 0 & 0 & 0 & 15 & 68 & 29 & 27 & 59 & 18 \\
\hline \multirow{2}{*}{$\mathrm{R} 6 / 50$} & B & 0 & 2 & 0 & 11 & 30 & 33 & 26 & 34 & 51 \\
\hline & $\mathrm{D}$ & 1 & 53 & 1 & 0 & 4 & 3 & 8 & 9 & 2 \\
\hline \multirow{2}{*}{$\mathrm{R} 7 / 85$} & $\mathrm{~B}$ & 7 & 3 & 0 & 9 & 25 & 13 & 27 & 23 & 28 \\
\hline & $\mathrm{D}$ & 28 & 2 & 0 & 0 & 0 & 0 & 0 & 1 & 7 \\
\hline
\end{tabular}

a) The experiment was carried out from autumn to winter. Inoculation was carried out 23 days after seeding

b) Average number of the lesions produced on the six half leaves of French bean cv. Top Crop.

c) Value of healthy leaf absorbance (average 0.02) was deducted. 0.00-0.04:-, 0.05-0.10:+, 0.11-0.49:

d) See Table 1 .

e) Leaf number. U: Unifoliolate leaf at unifoliolate node, 1: Trifoliolate leaf at the node above unifoliolate at the $n$th node from the unifoliolate leaf node.

f) Inoculated leaf.

g) Leaf was not developed.

Table 3. Detection of SMV in the leaves of

\begin{tabular}{|c|c|c|c|c|c|c|c|c|c|c|c|}
\hline \multirow{2}{*}{$\begin{array}{l}\text { Staged) } \\
\text { Days after } \\
\text { inoculation }\end{array}$} & \multirow{2}{*}{ Strain } & \multicolumn{10}{|c|}{ Bioassay b) } \\
\hline & & $U^{e)}$ & 1 & 2 & 3 f) & 4 & 5 & 6 & 7 & 8 & 9 \\
\hline \multirow{2}{*}{$\mathrm{V} 5 / 4$} & B & 0 & 0 & 0 & 3 & 0 & $-\mathrm{g})$ & - & - & - & - \\
\hline & $\mathrm{D}$ & 0 & 0 & 0 & 9 & 2 & - & - & 一 & - & - \\
\hline \multirow{2}{*}{$\mathrm{V7} / 10$} & B & 0 & 0 & 0 & 81 & 63 & 64 & 139 & - & - & - \\
\hline & $\mathrm{D}$ & 0 & 0 & 0 & 96 & 196 & 239 & 404 & - & - & - \\
\hline \multirow{2}{*}{$\mathrm{R} 1 /_{20}$} & B & 0 & 0 & 0 & 16 & 35 & 58 & 32 & 16 & 29 & 49 \\
\hline & $\mathrm{D}$ & 0 & 0 & 0 & 9 & 15 & 10 & 38 & 14 & 21 & 4 \\
\hline \multirow{2}{*}{$\mathrm{R} 4 /_{35}$} & $\mathrm{~B}$ & 0 & 0 & 0 & 29 & 38 & 43 & 54 & 51 & 78 & 81 \\
\hline & $\mathrm{D}$ & 3 & 0 & 0 & 12 & 0 & 0 & 8 & 20 & 15 & 13 \\
\hline \multirow{2}{*}{$\mathrm{R} 6 / 50$} & $\mathrm{~B}$ & $\left.f^{h}\right)$ & 2 & 0 & 7 & 32 & 34 & 48 & 28 & 25 & 39 \\
\hline & $\mathrm{D}$ & 2 & 0 & 0 & 0 & 0 & 0 & 0 & 0 & 0 & 8 \\
\hline \multirow{2}{*}{$\mathrm{R}^{\mathrm{R}} / 85$} & B & $\mathrm{f}$ & $\mathrm{f}$ & $\mathrm{f}$ & $\mathrm{f}$ & $\mathrm{f}$ & 13 & 8 & 0 & 7 & 17 \\
\hline & $\mathrm{D}$ & $\mathrm{f}$ & $\mathrm{f}$ & $\mathrm{f}$ & $\mathrm{f}$ & 0 & 0 & 0 & 0 & 0 & 1 \\
\hline
\end{tabular}

a) The experiment was carried out from spring to early summer. Inoculation was carried out 24 days after b)-g) See Table 2.

h) Defoliated.

detected from all leaves above the inoculated leaves. The detection values of SMV-D obtained by bioassay were higher than those of SMV-B, but the detection values of both strains decreased as the plants aged. The reduction in detection values, however, was more rapid in SMV-D than SMV-B. As the result the detection values of SMV-B became higher than those of SMV$\mathrm{D}$ from the 35 th to the 85 th day after inoculation (R4 to R7). At least, until the 35th day after inoculation (R4), the detection values obtained by bioassay and those by ELISA were similar. On the 50th and 85th days after inoculation (R6 and R7), viruses were faintly detected from the leaves lower than the inoculated leaves showing some discrepancies between detection values 
the inoculated soybean plants (First exp.) ${ }^{\text {a) }}$

\begin{tabular}{|c|c|c|c|c|c|c|c|c|}
\hline \multicolumn{9}{|c|}{ ELISA $^{c}$ ) } \\
\hline $\mathrm{U}$ & 1 & 2 & $3^{\text {f) }}$ & 4 & 5 & 6 & 7 & 8 \\
\hline - & - & - & ++ & - & - & - & - & - \\
\hline- & - & - & ++ & - & - & - & - & - \\
\hline- & - & - & +++ & +++ & ++++ & ++++ & - & - \\
\hline- & - & - & +++ & ++++ & ++++ & ++++ & - & - \\
\hline - & - & - & ++ & $+++t$ & ++++ & $+++t$ & $+++t$ & $+++t$ \\
\hline- & - & - & +++ & ++++ & $+++t$ & ++++ & ++++ & ++++ \\
\hline- & - & - & +++ & +++ & +++ & +++ & +++ & +++ \\
\hline- & - & - & +++ & +++ & +++ & +++ & +++ & +++ \\
\hline++ & - & - & ++ & +++ & +++ & +++ & +++ & +++ \\
\hline++ & +++ & - & ++ & $+t$ & ++ & ++ & ++ & ++ \\
\hline+++ & ++ & + & ++ & +++ & +++ & +++ & +++ & +++ \\
\hline+++ & $+++t$ & + & - & ++ & + & ++ & ++ & +++ \\
\hline
\end{tabular}

(V4).

$++, 0.50-0.99:+++, 1.00-:++++$.

leaf node, 2: Trifoliolate leaf at the third node beginning with the unifoliolate node, $\mathrm{n}$ : Trifoliolate leaf

the inoculated soybean plants (Second exp.) a)

\begin{tabular}{|c|c|c|c|c|c|c|c|c|c|}
\hline \multicolumn{10}{|c|}{ ELISA $\left.^{c}\right)$} \\
\hline $\mathrm{U}$ & 1 & 2 & $3^{f)}$ & 4 & 5 & 6 & 7 & 8 & 9 \\
\hline- & - & - & ++ & - & - & - & - & - & - \\
\hline- & - & - & $+t$ & ++ & - & - & - & - & - \\
\hline- & - & - & +++ & +++ & +++ & +++ & - & - & - \\
\hline- & - & - & +++ & ++++ & +++ & +++ & - & - & - \\
\hline- & - & - & +++ & $+t+$ & +++ & +++ & +++ & +++ & +++ \\
\hline- & - & - & +++ & +++ & +++ & +++ & +++ & +++ & ++ \\
\hline- & - & - & ++ & +++ & +++ & +++ & +++ & +++ & +++ \\
\hline++ & - & - & ++ & ++ & ++ & +++ & +++ & ++ & $++t$ \\
\hline $\mathrm{f}$ & ++ & - & ++ & +++ & +++ & +++ & ++ & +++ & +++ \\
\hline++ & - & - & ++ & - & + & + & + & ++ & $++t$ \\
\hline$f$ & $f$ & $\mathrm{f}$ & $\mathrm{f}$ & $f$ & ++ & ++ & + & ++ & $++t$ \\
\hline$f$ & $f$ & $f$ & $\mathrm{f}$ & - & - & - & + & ++ & ++ \\
\hline
\end{tabular}

seeding (V4).

of bioassay and ELISA. On the 85th day after inoculation (R7), SMV-B was still active in all leaves but by bioassay SMV-D was only detected from a few top and lower leaves. ELISA, however, detected SMV-D from leaves in which virus could not be detected by bioassay (Tables $2,3)$.

\section{Translocation of SMV in soybean seeds}

When the 1st trifoliolate leaf was inoculated at V6, both strains were detected only in the seeds from 2nd and 3rd nodes. In the case of inoculation at R1 (V8), no virus was detected in the seeds from any nodes. But in the cases of other positions and stages of inoculation, for 
Table 4. Translocation of SMV-B from inoculated leaf to soybean seeds ${ }^{\text {a) }}$

\begin{tabular}{|c|c|c|c|c|c|c|c|c|}
\hline \multirow{2}{*}{$\begin{array}{l}\text { Stage of } \\
\text { inoculation }\end{array}$} & \multicolumn{8}{|c|}{ Node number } \\
\hline & 2 & 3 & 4 & 5 & 6 & 7 & 8 & 9 \\
\hline $\mathrm{V} 2 \mathrm{~b})$ & $+* c)$ & $\left.+{ }^{d}\right)$ & + & + & + & + & + & $\mathrm{ns}^{\mathrm{e}}$ \\
\hline \multirow{2}{*}{ V4 } & $+^{*}$ & + & ns & + & + & + & + & + \\
\hline & ns & + & $+^{*}$ & + & + & $\mathrm{ns}$ & ns & + \\
\hline \multirow{3}{*}{ V6 } & $+^{*}$ & + & - & - & - & ns & ns & - \\
\hline & ns & + & $+^{*}$ & + & + & + & + & + \\
\hline & + & + & + & + & $+^{*}$ & + & ns & ns \\
\hline$R(f)$ & - & - & - & - & - & - & -* & - \\
\hline
\end{tabular}

a) The experiment was carried out in summer.

b) See Table 1 .

c) Node having inoculated leaf.

d) The results of detection from seeds at R6 stage by ELISA. Value of healthy seed absorbance (average 0.02) was deducted. 0.00-0.04:-, 0.05-: + .

e) ns: Seed was not set.

f) R1 stage equals V8 stage.

Table 5. Translocation of SMV-D from inoculated leaf to soybean seeds ${ }^{\text {a }}$

\begin{tabular}{|c|c|c|c|c|c|c|c|c|}
\hline \multirow{2}{*}{$\begin{array}{l}\text { Stage of } \\
\text { inoculation }\end{array}$} & \multicolumn{8}{|c|}{ Node number } \\
\hline & 2 & 3 & 4 & 5 & 6 & 7 & 8 & 9 \\
\hline$V 2 b)$ & $t^{*(c)}$ & $+^{d)}$ & + & + & $\left.n s^{\theta}\right)$ & ns & ns & $\mathrm{ns}$ \\
\hline \multirow{2}{*}{ V4 } & $+^{*}$ & + & ns & $\mathrm{ns}$ & $\mathrm{ns}$ & $\mathrm{ns}$ & $\mathrm{ns}$ & $\mathrm{ns}$ \\
\hline & + & + & $+^{*}$ & + & + & ns & ns & ns \\
\hline \multirow{3}{*}{ V6 } & $+^{*}$ & + & - & - & - & - & - & - \\
\hline & + & + & $+^{*}$ & + & + & + & ns & ns \\
\hline & + & + & + & + & $+^{*}$ & + & + & ns \\
\hline$R(f)$ & - & - & - & - & - & - & ns* & ns \\
\hline
\end{tabular}

a) The experiment was carried out in summer.

b) See Table 1 .

c)-f) See Table 4.

instance, inoculation to the 1st trifoliolate leaf at V2, to the 1st and 3rd trifoliolate leaves at V4 or to the 3rd and 5th trifoliolate leaves at V6, both virus strains were detected in the seeds harvested from every node regardless of the age of plant and inoculation position (Tables 4 , 5).

\section{DISCUSSION}

In the previous investigation ${ }^{7)}$ the authors indicated that the concentrations of SMV strains $B$ and $D$ in seed tissues decreased with seed maturation and drying, and that SMV-D decreased more rapidly than SMV-B, particularly in the embryo. The authors assumed that seed transmissibility is closely related to the stability of the virus strains in seed tissues. The results of this experiment (Tables 2, 3) indicated that the difference in stability between two SMV strains in soybean leaves resembled the stability in seed tissues. As shown in the duplicated experiments (Tables 2, 3), the detection values of SMV-D were higher than those of SMV-B even at 10 days after inoculation (V7). Subsequently the value of SMV-D quickly decreased, while SMV-B remained relatively constant between the 10th and 20th day after inoculation (V7 and R1). On 
the 85th day after inoculation (R7), SMV-D disappeared almost completely in many leaves while SMV-B remained in almost all leaves. In both experiments concerning SMV-D, an explosive multiplication in the early stage and a rapid decrease in the later stage were obvious. This strain may not have the complete affinity for the host, namely, early explosive multiplication of SMV-D may induce host resistance such as the inhibition of viral RNA production or the inactivation of virus in the host cells earlier than SMV-B. SMV-D causes the severe necrosis on the varieties having genes for resistance to SMV-B ${ }^{10}$. That symptom can be considered the consequence of the hypersensitive reaction. In the case of the soybean cv. Hyuga, the symptoms incited by SMV-D were not as severe and not accompanied with necrosis. For the purpose of understanding the reaction of host cells against SMV-B and SMV-D, electron microscopy studies concerning the cell structures of soybean cv. Hyuga infected by SMV-B and SMV-D have been planned, and the results will be presented in a subsequent paper.

Both strains were detected in the leaves lower than the inoculated leaves on the 50th and 85th days after inoculation (R6 and R7). The time lag in translocation of virus to the lower parts of host plant was described by Samuel as the results of the experiment with TMV-infected tomato plants ${ }^{9}$. He detected the virus in the lower leaves 10 days after inoculation. In our experiment, however, SMV was not translocated to the lower leaves until 50 days after inoculation. It was reported that the distant translocation of virus is closely related with translocation of the assimilates ${ }^{1,12)}$. Hume et al. indicated that very little photosynthesis products of soybean plants moved to the lower parts at the stages of R5 to R $6^{6}$. So the translocation pattern of SMV in soybean can be also said to be resemble to that of assimilates. In these lower parts, the multiplication of SMV-D was temporally higher than that of SMV-B. From the fact that the high level SMV-D antigen was detected by ELISA from the lower leaves on R7, it may be deduced that SMV-D multiplied highly in some lower leaves between R6 and R7 followed by a rapid decline of bioactivity.

To examine the mode of translocation of SMV-B and SMV-D from inoculated leaf to seeds, the authors inoculated both strains to the leaves of various positions of soybean cv. Hyuga at different stages and there was no difference between SMV-B and SMV-D in the patterns of translocation to seeds (Tables 4, 5). When inoculation was done to the 1st trifoliolate leaf at V6 stage, both strains were not detected in the seeds above 4th nodes. And in the case of inoculation at R1 stage (coinciding with V8), viruses did not translocate to the seeds. These facts suggest that the viruses multiplied in the aged leaves hardly translocated to the distant seeds, and after flowering even the viruses inoculated to the young leaves could not translocate to the seeds.

In the previous investigation ${ }^{7}$ the authors reported that SMV-B was detected by bioassay and ELISA from all tissues (seed coat, cotyledon and embryo) of seed at R6 and R7 stages, but SMV-D was not detected from cotyledon. Therefore, SMV-D detected from seeds in Table 5 mainly originated from seed coat. The results in Table 5 also indicate the inhibition of the setting seeds by SMV-D infection. Whether the SMV-D infected pollen is not capable of fertilization due to the poor germination as some other virus-host combinations ${ }^{2,13)}$ remains to be resolved. Anyhow, patterns of translocation from inoculated leaf to other leaves and seeds were same between SMV-B and SMV-D. However, in every infected leaf and seed SMV-D was inactivated more briefly than SMV-B (Tables 2, 3 and previous report ${ }^{7}$ ). As the result, almost only SMV-B remained in the embryo followed by having the chance of seed transmission.

The authors are grateful to Mr. M. Nakano, Kyushu National Agricultural Experiment Station and Mr. M. Iwasaki, Shikoku National Agricultural Experiment Station, for providing SMV-D and soybean seeds. We also appreciate the technical advice of Dr. T. Kawarabata, Institute of Biological Control, Kyushu University. 


\section{Literature cited}

1. Bennett, C.W. (1940). J. Agr. Res. 60: 361-390.

2. Childress, A.M. and Ramsdell, D.C. (1986). Phytopathology 76: 1333-1337.

3. Cho, E.K. and Goodman, R.M. (1979). Ibid. 69: 467-470.

4. Clark, M.F. and Adams, A.N. (1977). J. gen. Virol. 34: 475-483.

5. Fehr, W.R., Caviness, C.E., Burmood, D.T. and Pennington, J.S. (1971). Crop Sci. 11: 929-931.

6. Hume, D.J. and Criswell, J.G. (1973). Ibid. 13: 519-524.

7. Iwai, H., Ito, T., Sato, K. and Wakimoto, S. (1985). Ann. Phytopath. Soc. Japan 51: 475-481.

8. Nakano, M., Iwasaki, M. and Shinkai, A. (1982). Proc. Assoc. Pl. Prot. Kyushu 28: 24-25.

9. Samuel, G. (1934). Ann. appl. Biol. 21 : 90-111.

10. Takahashi, K., Tanaka, T., Iida, W. and Tsuda, Y. (1980). Bull. Tohoku Nat. Agr. Exp. Sta. 62: 1-130.

11. Tsuchizaki, T. and Omura, T. (1987). Ann. Phytopath. Soc. Japan 53: 478-488.

12. Worley, J.F. (1965). Phytopathology 55: 1299-1302.

13. Yang, A.F. and Hamilton, R.I. (1974). Virology 62: 26-37.

\section{和 文 摘 要}

岩井 久・脇本 哲：ダイズ植物体内に拉けるダイズモザイクウイルス B 系統および D 系統の増殖，移 行ならびに失活様式について

ダイズモザイクウイルス (SMV) の B 系統 (SMV-B) と D 系統 (SMV-D) の種子伝染性の差異の原因を明 らかにするために両系統のダイズ植物体内に挑ける移行, 増殖, 不活化の様式を検討した。ダイズ品種ヒュ ウガにおのおののウイルス系統を接種し，葉ならびに種子中のウイルス量を生物定量法拉よび ELISA によ って経時的に調べた。第 3 本葉期の第 3 本葉に接種した場合，接種後 10 日目には接種葉から上方に位置す るどの葉位葉内に打いても，SMV-D の汪うが SMV-Bよりも多量に増殖していた。その後植物体の加齢に 伴って両系統とも減少したが，その失活速度は SMV-D のほうが SMV-B よりも速やかであった。接種後 50 日目に両系統は接種葉より下方に位置する葉からもわずかに検出されたが，これらの葉においても SMVD の減少は SMV-B より顕著であった。さらに両系統を生育段階の異なるダイズの各葉位葉に接種した結 果，極端に老化した葉に接種した場合や開花期以降の植物の葉に接種した場合を除き，両系統とも容易に全 節の種子へ移行した。結局, 両系統の移行に大差はないものの，移行先の各器官（葉ならびに種子）内では， SMV-D の失活速度が SMV-B のそれを上回った。 